\title{
Therapeutic Potential of Cucumis Melo (L). Fruit Extract and Its Silver Nanopartciles Against Den Induced Hepatocellular Cancer in Rats
}

R Vidya ( $\square$ vidyabiochem@gmail.com )

Vels University: Vels Institute of Science Technology \& Advanced Studies https://orcid.org/0000-00018256-9847

K Kalaivani

Kongunadu Arts and Science College

P Amudha

Vels University: Vels Institute of Science Technology \& Advanced Studies

\section{Research Article}

Keywords: Cucumis melo (L), Silver nanoparticles, Hematological profile, Liver function markers, Tumor markers

Posted Date: August 6th, 2021

DOl: https://doi.org/10.21203/rs.3.rs-771986/v1

License: (c) (i) This work is licensed under a Creative Commons Attribution 4.0 International License. Read Full License

Version of Record: A version of this preprint was published at Applied Biochemistry and Biotechnology on November 18th, 2021. See the published version at https://doi.org/10.1007/s12010-021-03765-9. 


\section{Abstract}

Biosynthesized silver nanoparticles have a wide range of biological activities and using nanoparticles as one of the novel approaches in cancer therapy. In this present research work, the anticancer efficacy of Cucumis melo fruit extract and its silver nanoparticles was explored. Wistar rats were divided into six groups and hepatic cancer was induced with $0.01 \%$ DEN (diethylnitrosamine) through drinking water for 16 weeks. Cyclophosphamide was given as the standard drug at the dose of $50 \mathrm{mg} / \mathrm{kg}$ body weight. Hematological Parameters showed a decrease in the levels of hemoglobin $(\mathrm{Hb})$, packed cell volume (PCV), red blood cells (RBC), mean corpuscular volume (MCV), mean corpuscular $\mathrm{Hb}(\mathrm{MCH})$, mean corpuscular $\mathrm{Hb}$ concentration (MCHC), and platelets (PLTS) levels except white blood cell (WBC) in DEN induced cancer animals. Significant alterations in the hematological parameters were observed after treatment which indicate the protective effect of Cucumis melo fruit on the hemopoietic system. The levels of liver function markers such as transaminases (AST ALT, ALP, LDH, GGT and 5'NT were significantly elevated in serum and liver of cancer bearing rats. Treatment with crude extract and silver nanoparticles of Cucumis melo fruit, indicating that Cucumis melo fruit could have exerted its protective effect. The levels of serum tumor markers viz., Alpha feto protein (AFP) and Carcinoembryonic antigen (CEA) elevated in rats induced with DEN, which then were reduced following Cucumis melo fruit treatment, indicating the anticancer activity of the drug. Histological evaluation of liver and kidney were also performed to authenticate the present work.

\section{Introduction}

India is bestowed with the enormous biodiversity of medicinal plants. According to the World Health Organization estimates that up to 80 percent of people still rely mainly on traditional remedies such as herbs for their health needs due to better cultural acceptability, fewer side effects and better compatibility with the human body [1]. Nanotechnology, an interdisciplinary research field comprising chemistry, engineering, biology, and medicine, has great potential for early detection, meticulous diagnosis, and tailored treatment of cancer. Medicinal plants have been widely used for the treatment of diseases in a traditional way for several years. Herbal nanoparticles can be utilized to increase the herbal drug solubility and help to localize the drug in a specific site thus resulting in better efficacy and improved patient compliance. In the last 20 years, a variety of nanoparticle-based therapeutic and diagnostic agents are developed for the treatment of cancer, diabetes, pain, asthma, allergy and infections [2]

Hepatocellular carcinoma (HCC) is the most common form of primary liver cancer and affects more than half a million people worldwide, with the highest incidences in Asia and Africa [3]. It is the third leading cause of cancer death, and the global burden of HCC continues to increase worldwide $[4,5]$.

Diethylnitrosamine (DEN) may be a potent hepatocarcinogenic nitrosamine present in tobacco smoke, polluted water, cosmetics, cured meat products, and pharmaceutical agents [6] DEN-induced HCC is an accepted and widely-used an experimental model of hepatocarcinogenesis in humans [7].

Plants can be described as nano factories which provide a potential pathway to bioaccumulation into the food chain and the environment. Among the different biological agents, plants provide a safe and beneficial way to the synthesis of metallic nanoparticle as it is easily available so there is possibilities for large scale 
production aside from this the synthesis route is eco-friendly, the speed of production is quicker as compared to other biological models such as bacteria, algae and fungi [8]. Using plant extracts for silver nanoparticle synthesis, with a broad variety of metabolites that can aid in the reduction of silver ions, and are quicker than microbes in the synthesis.

The main mechanism considered for the method is plant-assisted reduction due to phytochemicals. The main phytochemicals involved are terpenoids, flavones, ketones, aldehydes, amides, and carboxylic acids, flavones, organic acids, of the ions [9]. Green synthesis is safer, ecofriendly and economic. The role of silver nanoparticles as an anti-cancer agent should open new doors in the field of medicine [10].

Cucumis melo (L.) is usually refereed as musk melon, cantaloupe. They belong to the family of Cucurbitaceae and are cultivated in all tropical regions of the world. They are rich sources of vitamin C, vitamin E, polyphenols and carotenoids, which have been suggested as natural sources of antioxidants [11]. Many phytochemicals having potential benefits are present in Cucumis melo fruit. The fruits are often used as a cooling, light cleanser or moisturizer for the skin and has stomachic properties. Traditionally, it is used for treatment of kidney stones, cancer, cardiovascular disorders and stroke [12].

Since the plant, Cucumis melo has been reported to possess antioxidant, anti-inflammatory, immune modulatory, anti-cancer and hepatoprotective activity [13], there is no systematic scientific studies on the anticancer effect of Cucumis melo fruit.

\section{Materials And Methods}

\section{Collection and Identification of Plant Material}

Cucumis melo (L.) (Family - Cucurbitaceae) fruits were collected from the local markets of Coimbatore district, Tamilnadu, India. The specimen sample was identified and authenticated by Dr. M. Palanisamy, Scientist-C, Botanical Survey of India, Southern Regional Centre, Coimbatore, Tamilnadu, India. The identification No. BSI/SRC/5/23/2014-15/Tech/482.

\section{Preparation of Fruit Extract}

The pulp of fresh fruits of Cucumis melo was chopped into pieces and dried at room temperature for 24 hours. The air-dried pulps were kept at $40 \otimes C$ in hot air oven for 24 hours to remove moisture content. The completely dried fruits were ground into powder by using a mixer grinder and stored. $10 \mathrm{~g}$ of the dried fruit powder was successively extracted with $100 \mathrm{ml}$ of selected solvents (water, methanol, ethanol, chloroform and ethyl acetate) using soxhlet apparatus and filtered through Whatmann No 1 filter paper. The filtrate was concentrated and dried under reduced pressure and controlled temperature. The concentrated extracts of fruit were stored in small vials at $-20^{\circ} \mathrm{C}$ and used for further analysis.

\section{Synthesis of silver nanoparticles from aqueous extract of Cucumis melo fruit}


The dried Cucumis melo fruit powder $(10 \mathrm{~g})$ was boiled in $100 \mathrm{ml}$ of distilled water for 10 minutes. The extract was cooled to room temperature filtered and used for the synthesis of SNPs. Aqueous solution of $1 \mathrm{mM}$ AgNO囚 was prepared and used for the synthesis of silver nanoparticles. $5 \mathrm{ml}$ of Cucumis melo fruit extract is mixed with $95 \mathrm{ml}$ of AgNOQ for the synthesis of silver nanoparticles. The synthesized silver nanoparticles are characterized by UV-visible spectroscopy, particle size analyzer, scanning electron microscope, Energy dispensive spectroscopy, x-ray diffraction analysis was carried out [14].

\section{Selection of Animals}

Healthy adult male wistar albino rats weighing about 150 to $200 \mathrm{~g}$ were obtained from Animal Breeding Centre, Kerala Agricultural University, Mannuthy, Thrissur, Kerala, India. They were housed in polypropylene cages under the standard laboratory condition $\left(25 \pm 2^{\circ} \mathrm{C}\right.$, humidity $60-70 \%, 12$ hours light / dark cycles). The animals were fed with commercial rat pellet diet (Sri ram animal foods, Coimbatore) and water was provided ad libitum. The rats were acclimatized to laboratory conditions for one week prior to the commencement of the experiment. The animal care and handling were done according to the regulations of Council Directive CPCSEA no: 659/02/a about Good Laboratory Practice (GLP) on animal experimentation. All animal experiments were performed within the laboratory according to the ethical guidelines suggested by the Institutional Animal Ethics Committee (IAEC).

\section{Induction of Hepatocellular Carcinoma}

The experimental hepatocellular carcinoma was induced by providing $0.01 \%$ DEN through drinking water for 16 weeks [15]. It is now widely used as a standard experimental model for HCC [16].

\section{Experimental Design}

After one week of acclimatization period, the animals were divided into five groups with six animals in each.

\section{Group I: Control rats fed with standard diet and water ad libitum.}

Group II: Rats induced with hepatocellular carcinoma by providing $0.01 \%$ DEN through drinking water for 16 weeks.

Group III: Rats treated with EECMF (500 mg / kg b.w) orally for 6 weeks after the administration of DEN for 10 weeks.

Group IV: Rats treated with SNPs-AECMF intraperitonially $(100 \mu \mathrm{g} / \mathrm{kg} \mathrm{b.w})$ for 6 weeks after the administration of DEN for 10 weeks.

Group V: Rats treated with standard drug Cyclophosphamide (50 mg/kg b.w) orally for 6 weeks after the administration of DEN for 10 weeks.

\section{Collection of Samples}


After the experimental regimen ( 16 weeks), the animals were sacrificed by cervical dislocation under mild chloroform anesthesia. Blood was collected in EDTA and centrifuge tubes by an incision made in the jugular veins and serum was separated by centrifugation at $2000 \mathrm{rpm}$ for 20 minutes and utilized for various biochemical assays. The liver and kidney were excised immediately and thoroughly washed in ice cold physiological saline and blotted dry. A part of the tissues such as liver and kidney were removed and fixed in $10 \%$ formalin for histopathological study. $10 \%$ of liver homogenate of the washed tissue was prepared in $0.1 \mathrm{M}$ Tris $\mathrm{HCl}$ buffer $(\mathrm{pH} \mathrm{7.4)}$ and utilized for the biochemical analysis.

\section{Analysis of Biochemical Parameters}

\section{Hematological Parameters}

The hematological parameters such as hemoglobin, PCV, WBC, RBC, platelets, $\mathrm{MCV}, \mathrm{MCH}$ and $\mathrm{MCHC}$ were assayed. The whole blood sample was analysed for the changes in the blood cells using SYSMEX Xs -800 i automatic hematology analyzer.

\section{Liver Function Markers}

The standard methods have been followed to analyze the liver function marker enzymes such as Aspartate transaminase, Alanine transaminase, alkaline phosphatase, Lactate dehydrogenase, $\mathbf{Y}$-Glutamyl transferase and 5'-Nucleotidase were analyzed $[17,18,19]$.

\section{Enzyme linked immunosorbant assay (ELISA) OF AFP and CEA}

The cancer marker enzymes alpha fetoprotein (AEP) and cancer embryonic antigen (CEA) was analyzed quantitatively using Enzyme Linked Immune Sorbent Assay (ELISA) technique [20].

\section{Histopathological studies - Liver and Kidney}

For histopathological examination, liver and kidney were fixed in $10 \%$ formalin and then embedded in paraffin wax. Paraffin embedded sample blocks were cut into 3-5 m sections using an ultra-microtome and processed for haematoxylin and eosin (H\&E) staining. Pathological changes in liver and kidney tissues were evaluated under light microscopy.

\section{Statistical analysis}

Results were expressed as mean \pm SD of six animals in each group. Statistical significance $(p<0.05)$ was determined by one-way analysis of variance (ANOVA) and post hoc least-significant difference (LSD) test using SPSS version 17.0.

\section{Result And Discussion}

\section{Effect of Cucumis melo Fruit and Its Silver Nanoparticles on Haematological Parameters}


The blood cells are the mobile units of the body's protective system. Anemia is frequently occurring in cancer patients [21]. Usually, in cancer chemotherapy the main problems that are being encountered are of myelosuppression and anemia [22]. Haematological parameters showed a decrease in the levels of $\mathrm{Hb}$, $\mathrm{RBC}, \mathrm{MCV}, \mathrm{MCH}, \mathrm{MCHC}$ and Platelets, and concomitant increase in WBC in DEN induced cancer animals. Significant alterations in the hematological parameters were observed in EECMF, SNPs-AECMF and cyclophosphamide treated rats which indicate the protective effect of Cucumis melo fruit on the hemopoietic system. Table 1 shows the levels of hemoglobin, lymphocyte count and RBC count in the control and experimental groups of rats.

Table 1 Effect of Cucumis melo fruit on hematological parameters of DEN induced HCC

\begin{tabular}{|c|c|c|c|c|c|c|c|c|}
\hline Groups & HB & PCV & WBC & RBC & Platelets & MCV & $\mathrm{MCH}$ & $\mathrm{MCHC}$ \\
\hline $\begin{array}{l}\text { Group I } \\
\text { (Control) }\end{array}$ & $\begin{array}{l}14.00 \\
\pm \\
0.14\end{array}$ & $\begin{array}{l}42.00 \\
\pm \\
0.42\end{array}$ & $\begin{array}{l}6.51 \\
\pm \\
0.11\end{array}$ & $\begin{array}{l}6.00 \\
\pm \\
0.14\end{array}$ & $\begin{array}{l}8.48 \pm \\
0.14\end{array}$ & $\begin{array}{l}55.50 \\
\pm \\
1.87\end{array}$ & $\begin{array}{l}21.83 \\
\pm \\
0.43\end{array}$ & $\begin{array}{l}33.16 \\
\pm 1.16\end{array}$ \\
\hline $\begin{array}{l}\text { Group II } \\
\text { (DEN induced) }\end{array}$ & $\begin{array}{l}9.55 \\
\pm \\
0.36 \\
a\end{array}$ & $\begin{array}{l}28.33 \\
\pm \\
1.03 \\
a\end{array}$ & $\begin{array}{l}13.98 \\
\pm \\
0.19 \\
a\end{array}$ & $\begin{array}{l}3.98 \\
\pm \\
0.14 \\
a\end{array}$ & $\begin{array}{l}4.46 \pm \\
0.21^{a}\end{array}$ & $\begin{array}{l}47.33 \\
\pm \\
1.75 \\
a\end{array}$ & $\begin{array}{l}18.18 \\
\pm \\
0.42^{a}\end{array}$ & $\begin{array}{l}27.08 \\
\pm 0.39 \\
a\end{array}$ \\
\hline $\begin{array}{l}\text { Group III } \\
\text { (DEN + EECMF) }\end{array}$ & $\begin{array}{l}11.20 \\
\pm \\
0.21 \\
\mathrm{bc}\end{array}$ & $\begin{array}{l}33.62 \\
\pm \\
0.63 \\
\text { b c }\end{array}$ & $\begin{array}{l}9.98 \\
\pm \\
0.54 \\
b\end{array}$ & $\begin{array}{l}5.50 \\
\pm \\
0.08 \\
b\end{array}$ & $\begin{array}{l}5.70 \pm \\
0.17^{\mathrm{b}}\end{array}$ & $\begin{array}{l}50.00 \\
\pm \\
1.41 \\
\mathrm{~b}\end{array}$ & $\begin{array}{l}19.51 \\
\pm \\
0.20 \\
b\end{array}$ & $\begin{array}{l}30.71 \\
\pm \\
1.21^{b}\end{array}$ \\
\hline $\begin{array}{l}\text { Group IV } \\
\text { (DEN + SNPs-AECMF) }\end{array}$ & $\begin{array}{l}12.33 \\
\pm \\
0.38^{b}\end{array}$ & $\begin{array}{l}37.73 \\
\pm \\
1.51^{b} \\
c\end{array}$ & $\begin{array}{l}7.73 \\
\pm \\
0.12 \\
b\end{array}$ & $\begin{array}{l}6.05 \\
\pm 0.18 \\
b\end{array}$ & $\begin{array}{l}6.58 \pm \\
0.16^{b}\end{array}$ & $\begin{array}{l}52.72 \\
\pm \\
1.23 \\
b\end{array}$ & $\begin{array}{l}20.45 \\
\pm \\
0.64 \\
b\end{array}$ & $\begin{array}{l}32.5 \pm \\
0.98^{b}\end{array}$ \\
\hline $\begin{array}{l}\text { Group V } \\
\text { (DEN+Cyclophosphamide) }\end{array}$ & $\begin{array}{l}13.03 \\
\pm \\
0.16\end{array}$ & $\begin{array}{l}38.85 \\
\pm \\
0.25\end{array}$ & $\begin{array}{l}7.83 \\
\pm \\
0.16\end{array}$ & $\begin{array}{l}6.38 \\
\pm 0.14\end{array}$ & $\begin{array}{l}7.08 \pm \\
0.23\end{array}$ & $\begin{array}{l}53.11 \\
\pm \\
0.27\end{array}$ & $\begin{array}{l}21.26 \\
\pm \\
0.16\end{array}$ & $\begin{array}{l}34.05 \\
\pm 0.18\end{array}$ \\
\hline
\end{tabular}

Values are expressed as mean \pm S.D for six animals

\section{Statistical comparison:}

a- Group II vs Group I b- Group III vs Group II, Group IV vs Group II c - Group III vs Group V and Group IV vs Group. The letters $a, b$ and $c$ represent the statistical significance at $p<0.05$.

Units : $\mathrm{Hb}-\mathrm{g} / \mathrm{dl}, \mathrm{PCV}-\%$, WBC - Thousands $/ \mathrm{mm}^{3}, \mathrm{RBC}-$ millions $/ \mathrm{mm}^{3}$, Platelets - lakhs $/ \mathrm{mm}^{3}, \mathrm{MCV}$ $-\mathrm{fL}, \mathrm{MCH}-\mathrm{Pg}, \mathrm{MCHC}-\mathrm{g} / \mathrm{dl}$ 
The levels of hemoglobin and RBC were found to be significantly $(p<0.05)$ decreased whereas WBC levels were significantly increased in (Group II) cancer bearing animals when compared with (Group I) control animals. Co-administration of EECMF and SNPS-AECMF, significantly altered the hematological parameters when compared with hepatocellular carcinoma induced rats. Significant variations were not observed in SNPs-AECMF (Group IV) treated rats compared to standard drug (cyclophosphamide) rats. Our finding is similar with the study of Althaf and Sudaroli who observed the significant reduction in the total WBC count and increase in the levels of hemoglobin and RBC when treated with ethanolic extract of Vitex leucoxylon Linn leaves on hepatocellular carcinoma induced rats [23]. Increased WBC count indicates the decreased resistance of the body to toxicity induced by DEN. Decreased RBC count and hemoglobin also indicate the severity of hepatic damage induced by DEN. Decrease in the hemoglobin levels might be due to increased catabolism and degradation of hemoglobin. Reduction in hemoglobin content can be related to decrease in RBC number which in turn indicates anemic induction [24]. Increased RBC, hemoglobin levels and other parameters indicated the protective effects of EECMF and SNPs-AECMF on the hemopoietic system.

\section{EFFECT OF Cucumis melo Fruit ON LIVER FUNCTION MARKERS}

The serum biomarkers and biochemical indicators can be an excellent tool or index to evaluate both functional and metabolic aspects of liver [25]. Several enzymes are produced in the liver and are normally distributed within the cells of the liver. Elevation of serum enzyme is taken as the sensitive biomarker of liver toxicity. The determination of various liver enzymes, alanine amino transferase (ALT), aspartate amino transaminase (AST), alkaline phosphatase ALP), i-glutamyl transpeptidase (i-GT), lactate dehydrogenase $(\mathrm{LDL})$ in serum helps to understand the functional status of liver and to detect liver injury. In the present study, DEN induced hepatocellular cancer is clearly evidenced by the marked elevation in serum SGPT, SGOT, GGT and ALP and a decreased level of these enzymes in the liver tissue, these biochemical marker enzymes are indicators of tumor response [26]. Serum GGT levels increased linearly with increases in small tumor mass, ALP levels are elevated in association with small tumors and further increases with increasing tumor mass [27].

ALP is used as a specific tumor marker during diagnosis in the early detection of cancer. It is well established that (ALT) levels signifies the presence of active disease and increases risk, particularly if the ALT is persistently or intermittently elevated over the years [28].

LDH is a cytosolic enzyme that catalyses the reversible oxidation of L-lactate to pyruvate. Their increased activity in serum confirms increased hepatocyte membrane permeability and cellular leakage. The levels of LDH is strongly correlated with tumor bulk as high rate of glycolysis takes place in cancerous condition, which is the only energy producing pathway for the malignant cells [29].

$\mathrm{i}-\mathrm{GT}$ is also believed to be an important indicator and the early enzyme marker of hepatocarcinogenesis. It is located in the outer membrane of the hepatic cells and their elevation reveals cholestasis and bile duct necrosis [30].

$5^{\prime}$-nucleotidase ( $\left.5^{\prime} \mathrm{NT}\right)$ is present at the bile canalicular and sinusoidal surface of the plasma membrane of hepatocytes. 5'NT hydrolyze nucleotides with a phosphate group on carbon atom of the ribose sugar and it 
was found to be elevated in cancer bearing animals. In addition, $5^{\prime} \mathrm{NT}$ is also used as a diagnostic tool for liver injury [31]. In the present investigation, an increased activity of $5{ }^{\prime} \mathrm{NT}$ activity was observed in hepatocellular carcinoma bearing animals. The elevation of the marker enzyme may be correlated with the progression of the malignancy and also due to the hepatic cell damage, which may cause leakage of 5 'nucleotidase into the circulation.

The activity of AST in the DEN induced carcinoma rats was found to be significantly increased in serum when compared to the control (Group I) rats. Similar trend was observed in the activities of ALT, ALP, LDH, GGT and 5'NT in serum of cancer bearing animals. Co-administration of EECMF and SNPS-AECMF treated rats caused a significant decrease in the levels of serum liver marker enzymes when compared to DEN induced rats (Group II). EECMF treated rats (Group III) was found to be significantly improved when compared with cyclophosphamide treated rats whereas significant difference was not observed in silver nanoparticles of aqueous extract of Cucumis melo fruit treatment.

Liver cancer induced rats (Group II) showed significantly $(p<0.05)$ elevated the levels of these enzymes when compared to control rats. Administration of EECMF and SNPs-AECMF treated rats significantly lowered the levels compared to cancer bearing animals. Significant changes were not observed in the silver nanoparticles treated rats (Group IV) when compared with standard drug cyclophosphamide treated rats. The activities of liver marker enzymes viz AST, ALT, ALP, LDH, GGT and 5'NT in liver of control and experimental rats is presented in Table 2.

Table 2 Effect of Cucumis melo fruit on the activities of hepatic marker enzymes in serum of DEN induced $\mathrm{HCC}$

\begin{tabular}{|c|c|c|c|c|c|c|}
\hline Groups & AST & ALT & ALP & LDH & GGT & $5^{\prime} \mathrm{NT}$ \\
\hline $\begin{array}{l}\text { Group I } \\
\text { (Control) }\end{array}$ & $\begin{array}{l}72.14 \pm \\
0.94\end{array}$ & $\begin{array}{l}142.77 \pm \\
1.53\end{array}$ & $\begin{array}{l}17.44 \pm \\
0.62\end{array}$ & $\begin{array}{l}358.78 \pm \\
1.84\end{array}$ & $\begin{array}{l}21.28 \pm \\
1.57\end{array}$ & $\begin{array}{l}3.28 \pm \\
0.21\end{array}$ \\
\hline $\begin{array}{l}\text { Group II } \\
\text { (DEN induced) }\end{array}$ & $\begin{array}{l}41.06 \pm \\
1.53^{\mathrm{a}}\end{array}$ & $\begin{array}{l}129.13 \pm \\
1.56^{a}\end{array}$ & $\begin{array}{l}32.45 \pm \\
1.32^{\mathrm{a}}\end{array}$ & $\begin{array}{l}432.46 \pm \\
2.06^{a}\end{array}$ & $\begin{array}{l}36.20 \pm \\
1.27^{a}\end{array}$ & $\begin{array}{l}7.50 \pm \\
0.14^{a}\end{array}$ \\
\hline $\begin{array}{l}\text { Group III } \\
(\text { DEN + EECMF) }\end{array}$ & $\begin{array}{l}46.68 \pm \\
2.38 \mathrm{bc}\end{array}$ & $\begin{array}{l}136.40 \pm \\
2.07 \mathrm{bc}\end{array}$ & $\begin{array}{l}28.02 \pm \\
1.11 \mathrm{bc}\end{array}$ & $\begin{array}{l}401.95 \pm \\
5.11^{\mathrm{bc}}\end{array}$ & $\begin{array}{l}31.64 \pm \\
0.98 \mathrm{bc}\end{array}$ & $\begin{array}{l}6.58 \pm \\
0.19 b c\end{array}$ \\
\hline $\begin{array}{l}\text { Group IV } \\
\text { (DEN + SNPs-AECMF) }\end{array}$ & $\begin{array}{l}56.00 \pm \\
0.87^{b}\end{array}$ & $\begin{array}{l}147.41 \pm \\
3.42^{b}\end{array}$ & $\begin{array}{l}26.46 \pm \\
2.08^{b}\end{array}$ & $\begin{array}{l}363.80 \pm \\
2.00^{b}\end{array}$ & $\begin{array}{l}28.40 \pm \\
1.68^{b}\end{array}$ & $\begin{array}{l}5.45^{ \pm} \\
0.18^{b}\end{array}$ \\
\hline $\begin{array}{l}\text { Group V } \\
\text { (DEN+Cyclophosphamide) }\end{array}$ & $\begin{array}{l}57.40 \pm \\
1.06\end{array}$ & $\begin{array}{l}149.30 \pm \\
1.41\end{array}$ & $\begin{array}{l}25.94 \pm \\
1.67\end{array}$ & $\begin{array}{l}365.90 \pm \\
2.97\end{array}$ & $\begin{array}{l}29.87 \pm \\
1.08\end{array}$ & $\begin{array}{l}5.25 \pm \\
0.22\end{array}$ \\
\hline
\end{tabular}

Values are expressed as mean \pm S.D for six animals 


\section{Statistical comparison:}

a- Group II vs Group I b- Group III vs Group II, Group IV vs Group II c - Group III vs Group V and Group IV vs Group $V$. The letters $a, b$ and $c$ represents the statistical significance at $p<0.05$.

Units: AST, ALT, LDH - $\mu$ moles of pyruvate liberated / min / mg protein, ALP - $\mu$ moles of phenol liberated / min / mg protein, GGT - $\mu$ moles of $p$ - nitroanilide liberated / min / mg protein, 5 ' NT - $\mu$ moles of phosphorus liberated / min / mg protein.

Polyphenolic extract of Blighia sapidaarilli fruits at various doses were administered to DEN-induced carcinoma rats showed the reduced activities of ALP, ALT and AST in liver and serum enzymes are reported [32]. Our result agrees well with elevated levels of serum AST, ALT, ALP, LDH, $Y-G T$ and bilirubin and simultaneous fall in the levels of the marker enzymes in the liver tissue induced by DEN was altered after the administration of ethanolic leaf extract of the medicinal plant Cassia fistula Linn [33]. The structural integrity of the cells has been damaged in cancer induced animals, and this results in cytoplasmic leakage of enzyme in to the blood stream, leads to the elevated levels of these enzymes in blood with subsequent fall in the tissues [34].

Hence, EECMF and SNPs-AECMF could have exerted their therapeutic effect against DEN induced HCC probably by preventing membrane damage, loss of integrity as well as by repairing hepatic tissue damage caused by tumor induction, thus inhibiting the release of these marker enzymes into the serum, indicating that Cucumis melo fruit has the ability to prevent further development of HCC.

\section{EFFECT OF Cucumis melo fruit ON THE LEVELS OF CANCER MARKERS}

For hepatocellular carcinoma (HCC), the common method of screening high risk patients by alphafetoprotein (AFP) and ultrasonography has been shown to result in earlier detection [35]. AFP is a 70-kD glycoprotein consisting of 591 amino acids and $4 \%$ carbohydrate residues, encoded by a gene on chromosome 4q11-q13. Normally produced during gestation by the fetal liver and yolk sac, AFP is highly elevated in the circulation of newborns with concentrations decreasing during the next 12 months to 10-20 $\mu \mathrm{g} / \mathrm{L}$. Only when serum levels of AFP rise above $500 \mathrm{ng} / \mathrm{ml}$, it is sufficiently specific for hepatocellular carcinoma (HCC) [36]. The serum marker, alpha fetoprotein (AFP) has been used as a diagnostic test for HCC [37]. AFP, as a specific sign of tumor, could provide the important referential value for cancer diagnosis, histopathological classification and prognosis. AFP content in tumor patient was remarkably higher than the normal tissue near carcinoma and the precancerous lesion tissue [38].

Carcino Embryonic Antigen (CEA) is an important tumor-associated antigen, and it's over expression has been used to identify or diagnose early colorectal, gastric, pancreatic, ovarian cancer and liver cancer. Over expression of CEA in serum always existed in metastatic HCC, and not in primary HCC. CEA are considered cDNA of fatty acid synthesis, tumor necrosis factor specific biomarkers for liver cancer and it is synthesized (TNF) and the house keeping gene-actin as a control, mainly in the fetal stage; practically no 
production of this were analyzed and the results of gene expression was marker occurs in the normal adult [39].

The levels of alpha feto protein and carcinoembryonic antigen in the serum of control and experimental rats are given in the Figure 1.

Values are expressed as mean \pm S.D for six animals

Group I- Control; Group II- DEN induced HCC; Group III- DEN + EECMF; Group IV- DEN + SNPs-AECMF; Group V- DEN + Cyclophosphamide

\section{Statistical comparison:}

a- Group II vs Group I; b- Group III vs Group II, Group IV vs Group II; c - Group III vs Group V and Group IV vs Group V. The letters $a, b$ and $c$ represents the statistical significance at $p<0.05$.

Hepatoma bearing rats (Group II) possessed increased levels of alpha feto protein and CEA when compared to control rats. Treatment with EECMF (Group III) and SNPs-AECMF (Group IV) decreased the levels of AFP and CEA when compared to DEN induced HCC rats (Group II). Treatment with the EECMF and SNPs-AECMF caused a significant depletion in the levels of AFP and significant difference was not recorded when compared to standard drug treated rats. Administration of limonin isolated from orange and lemon seeds, decrease the tumor marker AFP levels might against

$\mathrm{N}$-nitrosodiethylamine (DEN, $200 \mathrm{mg} / \mathrm{kg}$ ) induced phenobarbital promoted experimental hepatocellular carcinoma in male wistar albino rats. Morin (3, 5, 7, 2', 4'-pentahydroxyflavone), a plant-derived flavonoid significantly lowered the AFP and CEA levels in DEN-induced cancer rats [40].

Exposure of rats to certain carcinogens like DEN causes an elevation of circulating AFP level. CEA is cleared from the circulation by the liver with significant traces taken up by the spleen and lungs. An increase in serum CEA levels upon DEN treatment was presumably associated with production rates of tumor, its location and stage, size, differentiation and vascularity [41]. Upon liver injury these enzymes enter into the circulatory system due to altered permeability of the membrane. The observed reduction in the levels of AFP and CEA in EECMF and SNPs- AECMF treated animals might be due to a decrease in the rate of tumor development, indicating their anticancer activity because of the presence of alkaloids, flavanoids, terpenoids and other phytochemicals of Cucumis melo fruit extract [42].

\section{Histopathological Investigations of Liver and Kidney}

Microscopic observations of Cucumis melo fruit treated DEN-induced rat liver are given in Figure 2 shows the histopathological examination of liver and kidney. Control (Group I) rats revealed normal liver hepatocytes with granulated cytoplasm, small uniform nuclei, and central vein surrounded by cords of hepatocytes and normal architecture. Group II (DEN-induced) rats showed loss of architecture and lobules of neoplastic hepatocytes with a focal area of fatty change. Group III (EECMF) rats exhibited DEN showed a moderate cancerous change, fatty change, and hydropic degeneration. Groups IV (SNPs-AECMF) and Group 
V (Standard drug) rats showed fewer neoplastically-transformed cells and the hepatocytes maintained nearnormal architecture.

The histological study of rat kidneys showing Group I renal glomerular tubules and normal architecture. Group II (DEN induced HCC rats) showing blood vessel congestion and inflammatory infiltration. Group III (EECMF treated rats) shows moderate renal glomeruli congestion of intersitial blood vessels and hemorrhage with minimal inflammatory infiltration. Group IV (SNPs-AECMF) and Group V (Cyclophosphamide) treated rats shows mild glomeruli congestion with narrow focal dilation and mild inflammatory infiltration.

Histopathological investigation of liver showed loss of architecture and lobules of neoplastic hepatocytes with a focal area of fatty change in DEN induced liver cancer rats. These changes were found to be reduced tremendously in EECMF, SNPs-AECMF and standard drug cyclophosphamide treated animals. Kidney of cancer induced rats showed tubular damage and portal inflammation within due to glomerular damage. The kidney of treated rats with EECMF and SNPs- AECMF showed the mild portal inflammation. Treatment with Cucumis melo fruit extract showed the improvement in the architecture of liver and kidney of cancer rats which might be due to the reduction in the cancerous condition of the organs.

\section{Conclusions}

The ethanolic extract and silver nanoparticles of aqueous extract of Cucumis melo fruit possess potent antioxidant and anticancer activities.

The anticancer activity of the silver nanoparticles of aqueous extract of Cucumis melo fruit was similar to that of rats treated with standard drug cyclophosphamide, proving the effective anticancer potential against DEN induced hepatocellular carcinoma in rats. Silver nanoparticles of Cucumis melo fruit extract may easily enter in to the cancer cells which are having larger pore size compared to normal cells. Hence, sizecontrolled targeting of silver nanoparticles can prove their effectiveness in cancer treatment, might be due to the morphological differences between cancer and the other normal cells. Silver nanoparticles of aqueous extract of Cucumis melo fruit was found to exhibit the anticancer effect only on the tumor cells (chemotherapeutic effect) but not on the normal cells revealed by toxicity studies (pharmaco dynamic effect). The present investigation conclusively substantiates that the anticancer potential of ethanolic extract and silver nanoparticles of Cucumis melo fruit, might be due to the additive and synergistic effects of the secondary metabolites such as alkaloids, flavonoids, terpenoids and other phytochemicals of Cucumis melo fruit. The molecular mechanism of silver nanoparticles inhibits the tumor growth have yet to be explored.

\section{Abbreviations}

EECMF- Ethanolic extract of Cucumis melo fruit; SNPs-AECMF- silver nanoparticles of aqueous extract of Cucumis melo fruit; ACP- acid phosphatase; ALP- alkaline phosphatase; ALT- Alanine transaminase; ASTaspartate transaminase; EDTA- ethylene diamine tetra acetic acid. 


\section{Declarations}

\section{Conflict of Interest}

The authors declare that they have no conflict of interest.

\section{References}

1. Thevasundari, S and Rajendran, A. (2011) Antibacterial Potential and Phytochemical analysis of Heterostemma tanjorense (wight and arn). World J Sci Technol. 1(11), 39-45.

2. Kawasaki, E.S and Player, A. (2005) Nanotechnology, nanomedicine, and the development of new, effective therapies for cancer. Nanomed. 1,101-109.

3. Jemal, A., Bray, F., Center, M.M., Ferlay, J., Ward, E and Forman, D. (2011) Global cancer statistics. CA Cancer J Clin. 61, 69-90.

4. Wei, Q., Mu, K., Li, T., Zhang, Y., Yang, Z., Jia, X., Zhao, W., Huai, W., Guo, P and Han, L. (2014) Deregulation of the NLRP3 inflammasome in hepatic parenchymal cells during liver cancer progression. Lab Invest. 94(1), 52-62.

5. Zhu, X.L., Wang, Y.L., Chen, J.P., Duan, L.L., Cong, P.F., Qu, Y.C., Ling, J.L and Zhang, M.X. (2014) Alternol inhibits migration and invasion of human hepatocellular carcinoma cells by targeting epithelial-tomesenchymal transition. Tumour Biol. 35(2), 1627-1635.

6. Sun, H., Yu, L., Wei, H and Liu, G. (2012) A novel antihepatitis drug, bicyclol, prevents liver carcinogenesis in diethylnitrosamine initiated and phenobarbital-promoted mice tumor model. $\mathrm{J}$ Biomed Biotechnol. 584-728.

7. Sivaramakrishnan, V., Shilpa, P.N., Praveen-Kumar, V.R and Niranjali-Devaraj, S. (2008) Attenuation of Nnitrosodiethylamine induced hepatocellular carcinogenesis by a novel flavonol- Morin. Chem Biol Interact. 171, 79-88.

8. Nour, A.E.M., Eftaiha, A., Al-Warthan, A and Ammar, R.A. (2010) Synthesis and applications of silver nanoparticles. Arab J Chem. 3, 135-140.

9. Jha, A.K, Prasad, K., Prasad, K and Kulkarni, A.R. (2009) Plant system: nature's nanofactory. Colloids Surf. B Biointerfaces.73, 219-223.

10. Vaidyanathan, R., Kalishwaralal, K and Gopalram, S. (2009) Nanosilver the burgeoning therapeutic molecule and its green synthesis. Biotechnol Adv. 27, 924-37.

11. Lester, G.E., Jifon, J.L and Crosby, K.M. (2009) Superoxide dismutase activity in mesocarp tissue from divergent Cucumis melo L. genotypes. Plant Foods Hum Nutr. 64(3), 205-211.

12. Ritschel, P.S., Lins, T.C., Tristan, R.L., Buso, G.S., Buso, J.S and Ferreira, M.E. (2004) Development of microsatell markers from an enriched genomic library for genetic analysis of melon (Cucumis melo L.). BMC Plant Biol. 4, 9.

13. Parlie, M and Singh, K. (2011) Musk melon is eat must-melon. Int J Pharm Sci Rev Res., 2(8): 52-57. 
14. Vidya, R and Kalaivani K. (2020) Green synthesis of silver nanoparticles and its characterization using Cucumis melo (L). Fruit extract. Int. J. Bot Studies. 5,5, 99-103

15. Ramakrishnan, G., Raghavendran, H.R., Vinodhkumar, R and Devaki, T. (2006) Suppression of Nnitrosodiethylamine induced hepatocarcinogenesis by silymarin in rats. Chem Biol Interact. 161, 04114.

16. Sivaramakrishnan, V and Devaraj, S.N. (2009) Morin regulates the expression of NF- ${ }_{k}$ B-p65, COX-2 and Matrix metalloproteinases in diethylnitrosamine induced rat hepatocellular carcinoma. Chem Biol Inter. 180, 353-359.

17. King E.J, Armstrong A.R. (1934) Estimation of alkaline phosphatase. Canad. Med. Assoc. J. 311, 152156.

18. Reitman S, Frankel S. A. (1957) Calorimetric method for the determination of serum glutamic oxalacetic and glutamic pyruvic transaminase. American J. Clin. Pathol. 28(1), 56-63.

19. King J. (1954), in the hydrolases - acid and alkaline phosphatase. Practical Clinical Enzymology. London: Kerstin Company Ltd. pp. 191-208.

20. Sell S, Beckar FF. (1978) Alpha fetoprotein. Natl Cancer Inst. 60(1), 19-26.

21. De Vita, V.T., Hellman, S and Rosenberg, S.A. (1993). (Editors). Cancer: principle and practice of oncology, 4th Edition. JB. Lippincott Company, Philadelphia.

22. Hogland, H.C. (1982) Hematological complications of cancer chemotherapy. Semi Oncol. 9, 95-102.

23. Althaf Faimum, D and Sudaroli. (2012) Influence of Vitex Leucoxylon Linn on Oxidative Stress and Hepatocarcinogenesis induced By Diethylnitrosamine and Phenobarbital In Rats. Int J Toxicol Pharmacol Res. 4(4), 96-107.

24. Sarantchandra, G., Chandre, J., Jayasuder, S and Murthy, P.B. (1996) Toxicology of Cleistanthus collinus an indigeneous plant acute toxicity study. Indian J Toxicol. 3, 9-17.

25. Deepa, K., Ingawalea., Satish, K., Mandlikb., Suresh, R., and Naika. (2014) Models of hepatotoxicity and the underlying cellular, biochemical and immunological mechanism(s): A critical discussion. Environ Toxicol Pharmacol. 37, 118-133.

26. Carr, B.I., Lu, S.N and Pancoska, P., (2011) Small hepatocellular carcinoma in Chinese patients. Hepatogastroenterol. 58(109), 1334-1342.

27. Pancoska, P., De Giorgio, M., Fagiuoli, S and Carr, B.I. (2011) Small HCCs identified by screening. Dig. Dis. Sci. 56 (10), 3078-3085.

28. Sherman, M. (2009) Risk of hepatocellular carcinoma in hepatitis B and prevention through treatment Cleveland. Clin J Med. 76(3), 6-9.

29. Nandakumar, N., Jayaprakash, R., Rengarajan, T., Ramesh, V and Balasubramanian, M.P. (2011) Hesperidin, a natural citrus flavonoglycoside, normalizes lipid peroxidation and membrane bound marker enzymes in 7, 12-Dimethylbenz (a) anthracene induced experimental breast cancer rats. Biomed Prev Nutr. 1, 255-262.

30. Reynaert, H., Vaeyens, F., Qin, H., Hellemans, K., Chatterjee, N., Winand, D., Quartier, E., Schuit, F., Urbain, D., Kumar, U., Patel, Y.C and Geerts, A. (2001) Somatostatin suppresses endothelin-1-induced rat 
hepatic stellate cell contraction via somatostatin receptor sub type 1. Gastroenterol. 121, 915-930.

31. Fredericks, W.M., Cornelis, J.F., Noorden, V., Aronson, D.C., Maex, F., Bosch, K.S., Jonges, G.N., Vogels, I.M and James, J. (1990) Quantitative changes in acid phosphatase, alkaline phosphatase and 5'nucleodidase activity in rat liver after experimentally induced cholestasis. Liver. 10, 158-166.

32. Oloyede, O.B., Taofeek, O.A and Yesirat, O.K. (2013) N-nitrosodiethylamine induced redox imbalance in rat liver: Protective role of polyphenolic extract of Blighiasapidaarilli. Free Radicals and Antioxid. 3, 2529.

33. Pradeep, K., Rajmohan, C.V., Gobianand, K and Karthikeyan, S. (2010) Protective effect of Cassia fistula Linn. on diethylnitrosamine induced hepatocellular damage and oxidative stress in ethanol pretreated rats. Biol Res. 43, 113-125.

34. Thapa, B.R and Walia, A. (2007) Liver function tests and their interpretation. Indian J Pediatr. 74(7), 663-671.

35. Pournima, M., Seema, M.J., Manisha, K and Vilasrao, K. (2012) Biomarkers in oncology J Appl Pharm Sci. 2(3), 182-191.

36. Tan, H.T., Low, J., Lim, S.G and Chung, M.C.M. (2009) Serum autoantibodies as biomarkers for early cancer detection. Febs J. 276(23), 6880-6904.

37. Debruyne, E.N and Delanghe, J.R. (2008) Diagnosing and monitoring hepatocellular carcinoma with alpha-fetoprotein: New aspects and applications. Clinica Chimica Acta. 395, 19-26.

38. Marchesi, M.C., Conti, M.B., Pieramati, C., Mangili, V and Fruganti, G. (2007). Assessment and behavior of Alphafetoprotein (AFP), Antigen Cancer15/3 (CA15/3), Carcinembryonal Antigen (CEA) in clinical oncology of the dog: preliminary study. Vet Res Commun. 31, 301-304.

39. Ghada, M.A., Ragab., Ezzeldeen, S., El-Denshary., Aziza, M., Hassan., Sekena, H., Abdel- Azeim., Nabila, S., Hassan., Fathia, A., Mannaa and Mosaad A., Abdel-Wahhab. (2013) Grape (Vitis vinifera) Seed Extract Inhibits the Cytotoxicity and Oxidative Stress in Liver of Rats Treated with Carbon Tetrachloride. Glo J Pharmacol. 7(3), 258-269.

40. Kulanthaivel, L., Subbaraj., Gowtham, K., Srinivasan, P., Rajendran, R and Maruthaiveeran, P. (2013) Limonin-A citrus limonoid, establish anticancer potential by stabilizing lipid peroxidation and antioxidant status against $\mathrm{N}$ - nitrosodiethylamine induced experimental hepatocellular carcinoma. Biomed Preventive Nutr. 3, 165-171.

41. Zimmer, R and Thomas, P. (2001) Mutations in the carcinoembryonic antigen gene in colorectal cancer patients: implications on liver metastasis. Cancer Res. 61, 2822-2826.

42. Al-Attar, A.M. (2011) Hepatoprotective influence of vitamin $C$ on thioacetamide-induced liver cirrhosis in Wistar male rats. J Pharmacol Toxicol. 6, 218-233.

\section{Figures}




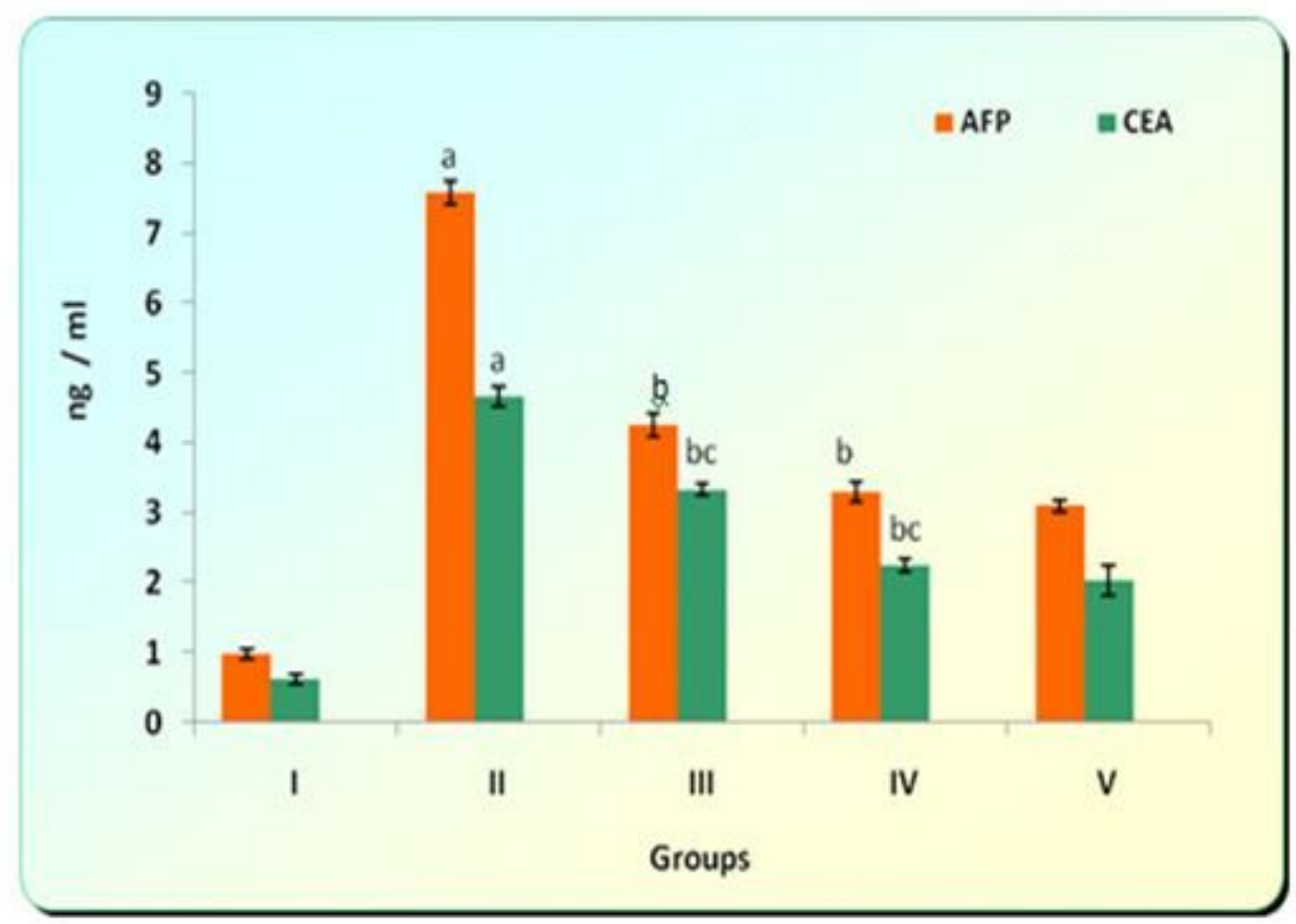

Figure 1

Effect of Cucumis melo fruit on the levels of cancer markers in serum of DEN induced HCC

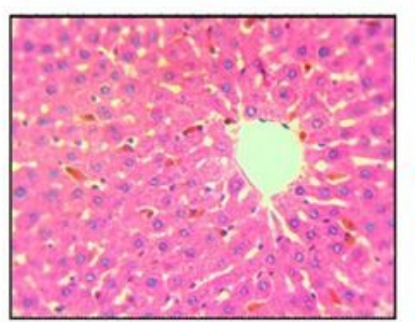

GROUP I - Control

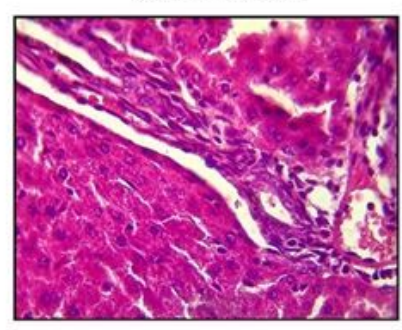

GROUP III - DEN + EECMF

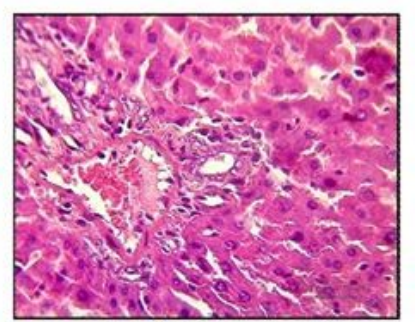

GROUP II - DEN

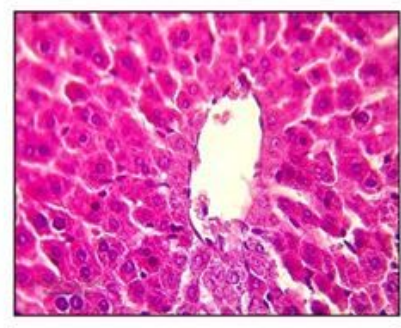

GROUP IV - DEN + SNPS-AECMF

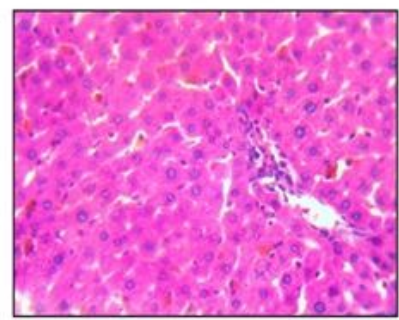

GROUP V - DEN + Cyclophosphamide

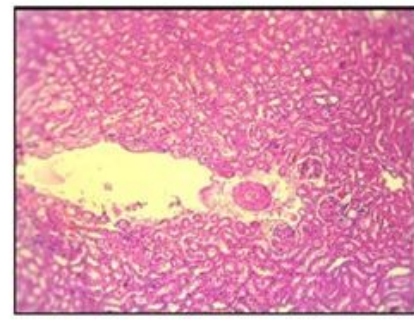

GROUP I - Control

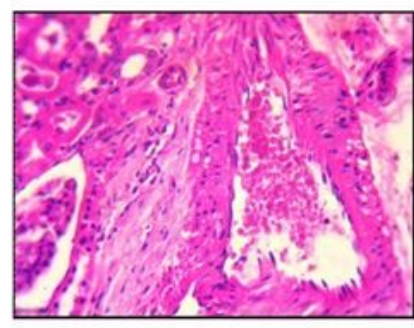

GROUP III - DEN + EECMF

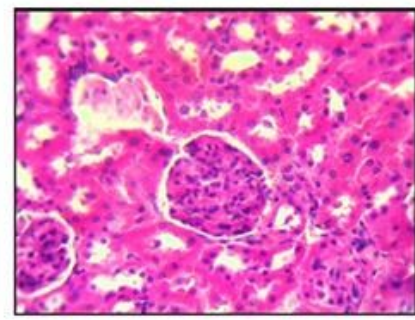

GROUP II - DEN

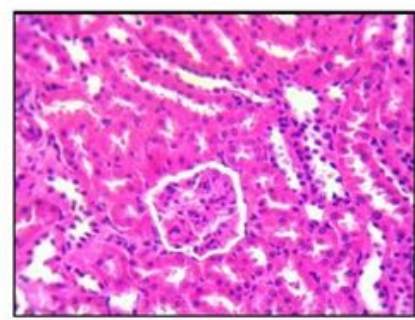

GROUP IV - DEN + SNPS-AECMF

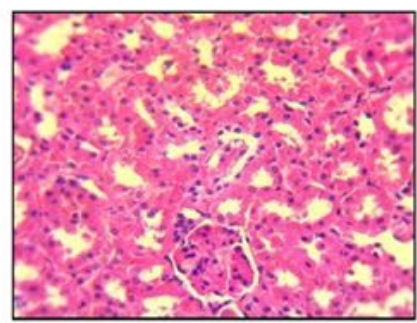

GROUP V - DEN + Cyclophosphamide

Figure 2 
Histopathological architecture of liver Histopathological architecture of kidney

Page 16/16 